His own clinical research programme in bladder cancer not only generates classical mRNA expression and proteomic data from normal and diseased biopsy samples, but also identifies the exact cellular location of proteins in the same biopsies using specific antibodies. This is time-consuming, particularly as most of the antibodies required have to be made in-house. Classical production of monoclonal antibodies in mice takes many weeks.

Many biologists believe that finding new ways to make high-quality antibodies on a large scale could lead to a second proteomics revolution. Promising ideas for efficient antibodygeneration are already being tested. One of these, pioneered by Greg Winter at the Laboratory of Molecular Biology in Cambridge and the company Cambridge Antibody Technologies, uses bacterial phages to generate antibodies. Another idea, pioneered by the Swedish Centre for Proteomics in Stockholm, uses combinatorial protein chemistry to generate potential artificial antibodies.

If these, or any other method, could lead rapidly to the creation of a library of highly specific, high-affinity antibodies that could reliably identify each individual protein in the proteome, proteomics could become a highly automated, high-throughput science like genomics. The antibodies could eventually be placed on chips, much like the cDNA arrays used in transcriptomics (see page 718 ).

Even in the near future, however, proteomics conducted on a limited scale has much to offer clinicians and basic biologists, and the decisions of funding agencies show that this is becoming more widely recognized (see below). Indeed, these decisions suggest that it may not be premature to start to discuss the realization of a longer-term goal, a Human Proteome Project.

Such a move would provide an invaluable tool for basic biologists and pharmaceutical companies alike, just as the Human Genome Project is providing a freely available tool in the form of complete genomic information. It would be several orders of magnitude more complex. But it would help drive the development of technologies to speed up the task, leading to a far more complete understanding of the operation of the human body than genomics alone can ever provide. Alison Abbott

\section{Funding agencies move hesitantly to embrace novel approaches}

One of the first funding agencies to recognize the potential of protein analysis was the US National Science Foundation. In 1989 it agreed to support the start of a ten-year programme at the University of Washington in Seattle to create a centre in molecular biotechnology, specializing in the development of proteomics tools.

Others were relatively slow to follow. The Danish Ministry of Research promoted several programmes in the early and mid-1990s, and Australia's Ministry of Science and Technology funded a Proteome Analysis Facility in the mid-1990s. These did much to spark development of proteomic technologies.

But it is only in the past couple of years that funding agencies have generally started to take proteomics seriously as a key postgenomic approach to biological problems.

The UK Biotechnology and Biological Sciences Research Council, for example, has recently funded three centres to establish transcriptomics and proteomics programmes in organisms whose genomes are sequenced, or close to completion. These are the fruitfly Drosophila, the yeast Saccharomyces cerevisiae, the plant Arabidopsis and the bacterium Streptomyces coelicolor.

"We see the approach of launching parallel initiatives in transcriptomics and proteomics as one of our most important scientific priorities in the next few years," says Ray
Germany has not thrown itself into proteomics to a great extent, although ironically 2D gel technology was invented in 1975 by Joachim Klose, now at the Max Planck Institute for Molecular Genetics in Berlin. Last year the federal research ministry awarded DM14 million (US\$7.3 million) for five years to set up a proteomics centre in Rostock to improve techniques and evaluate them in clinical projects in east Germany.

But this is a fairly isolated action. No dedicated proteomics project will be funded in the second round of the federal government funded German Human Genome Programme, even though this has prioritized post-genomic technologies.

Peter Jungblut, protein-analysis group leader at the new Max Planck Institute for Infection Biology in Berlin, uses proteomics approaches to define new targets for vaccine development. He says the attitude in Germany is "disappointing - but it is typical that Germany waits for new ideas to be developed in other countries before catching on".

Japan, like Germany, is hesitating before embracing large-scale proteomics. The Science and Technology Agency is requesting a $¥ 284$ million (US $\$ 2.7$ million) investment in proteomics research from the government.

"But the government is reluctant to make a full commitment to proteomics," says Teruhisa Noguchi, former director of the Helix Research Institute, a genomics centre that is contemplating a shift in emphasis towards proteomics, whether or not major government investment comes through. Helix is funded by the Ministry of International Trade and Industry and ten pharmaceutical companies.

Switzerland has no funding specifically earmarked for proteomics. But the Geneva-

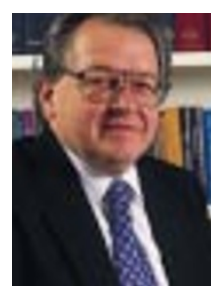

Radda: expects many grant applications. based Swiss Institute for Bioinformatics is a proteomics flagship for the country, looking after several public protein databases. Headed by Denis Hochstrasser, the institute is financed by the city of Geneva, and is run on proceeds from a new commercial arm, GeneBio, which licenses pharmaceutical companies access to its protein databases (see Nature 394, 214; 1998). GeneBio returns 75 per cent of its profits to the institute.

The pharmaceutical industry is watching developments with interest. Most companies have modest proteomics programmes inhouse, and often collaborate with academic groups on projects likely to drive the technology. Many use service companies, such as Oxford GlycoSciences and Large Scale Biology, for larger clinical projects. But, before investing in large in-house programmes, they are waiting to see if proteomics fulfils its potential as a discovery tool. 